\title{
Evaluation Instruments of Dance Learning Outcomes Based on Theory of Multiple Intelligences in Elementary School
}

\author{
Heni Siswantari ${ }^{1 *}$, Anugrah Maretha ${ }^{1}$ \\ ${ }^{1}$ Department of Elementary Teacher Education, Faculty of Teacher Training and Education, \\ Ahmad Dahlan University, Yogyakarta, Indonesia \\ *heni.siswantari@pgsd.uad.ac.id
}

Received: July $28^{\text {th }}, 2020$

Revised: August $07^{\text {th }}, 2020$

Accepted: August $10^{\text {th }}, 2020$

\begin{abstract}
This evaluation instrument is an instrument that emphasizes multiple intelligences that are used to assess the process and results of dance learning. This study aims to develop and find out the quality of evaluation instruments for dance learning outcomes based on multiple intelligences in elementary school students. This research is a type of Research and Development (RnD) development research using ADDIE (Analysis, Design, Development, Implementation, and Evaluation) development models. This research was tested on the fourth grade teachers of a private Islamic elementary school in Bantul City. Data collection techniques using expert validation sheets and teacher assessment sheets, then analyzed using quantitative data and qualitative data. The results of this study indicate that research and development has been carried out using the ADDIE model. The results of the assessment of learning experts get a value of 92.5 in the excellent category, material experts get a score of 94 in the excellent category, the evaluation expert gets a score of 77.5 in the good category, and the teacher's test scores 95 in the excellent category. Thus the average of all ratings scored 93.83 in the excellent category. Based on the test, the validity of the questions met the valid criteria. The reliability of multiple choice questions was 0.58 with sufficient criteria and description of 0.67 with sufficient criteria. So the instrument for evaluating dance learning outcomes based on multiple intelligences has good quality.
\end{abstract}

Keywords: dance learning; evaluation instrument; multiple intelligence.

\section{MAIN SECTION}

Learning of dance in elementary school is one material that can be used to develop a child's personality (Sundari \& Setyo, 2016). In dance learning, there are not only elements of wiraga (kinestetic), wirasa (sense), and wirama (musical) only. However, other intelligences are included in dance learning, namely multiple intelligences.
According to Arifin (2017) said that the theory of multiple intelligences is one of the most important and most promising developments in education today. Learning process in elementary school shows that intelligence is the ability possessed by a person which includes knowledge, skills, and expertise to solve the problem (Rofiah, 2016). Multiple intelligences more deeply explain there 
are 9 kinds of human intelligence including language, musical, logicmathematical, visual-spatial, kinestheticbodily, intrapersonal, naturalist, and spiritual-existence (Yaumi \& Nurdin, 2013).

In the learning process, evaluation is very important and one of the stages that must be taken by the teacher to determine the effectiveness of learning. Learning evaluation is a process or effort that is deliberately planned in a directed and systematic manner so that the series of activities is not careless, but the results of mature thought (Dirman \& Juarsih, 2014). Evaluating learning, among others, uses instruments (as an evaluation tool). Evaluation instruments can be used to carry out planned and directed assessments. So that the evaluation instrument can facilitate teachers in conducting assessments and can find out the extent of the development of students using these instruments. Dancing ability assessment instruments that have been developed can be used to measure students' dancing skills (Rosnawati, 2017).

Dance instructors so far only assess the aesthetic aspects or dance skills, namely by the body, nature, and choreography. The psychomotor assessment is more emphasized by looking at manipulative and imitative aspects in dancing a dance on the aspect of dance only evaluating the final results using authentic assessments following the 2013 curriculum and not evaluating during the dance learning process. While authentic assessment has not shown aspects of comprehensive assessment related to multiple intelligence processes students'. In evaluating dance learning it should not be limited to assessing students' dancing abilities, but teachers must also look at other intelligence that are owned by students. Other intelligence that can be assessed or evaluated in dance learning is multiple intelligences. So the teacher needs an evaluation instrument based on multiple intelligences that can be used to evaluate children's learning outcomes and to find out the child's overall development.

An instrument is a tool used to collect user data or information. The instrument for evaluating dance learning outcomes based on multiple intelligences is different from other instruments because the instrument developed is an evaluation instrument that is carried out to assess a process and learning outcomes of dance based on multiple intelligences rather than to the final result because in general when doing the teacher dance learning process only limited to observing the ability of students without using an evaluation instrument based on multiple intelligences. So that this evaluation instrument has a difference that lies in the contents of the instrument that is an evaluation instrument for dance learning based on multiple intelligences.

This paper is present to describe the development of dance learning evaluation instruments based on multiple intelligence on elementary school students. This instrument is important in the process of learning evaluation to 
facilitate teachers in seeing student intelligence that can appear in dance learning. Through this instrument, it can also show the contribution of dance learning in supporting the intelligence of students in following other subjects. This paper describes the procedure for developing an evaluation instrument for dance learning based on multiple intelligences for elementary schools which were developed based on Howard Gadner's theory of multiple intelligences and reviewed in Indonesian by Yaumi and Nurdin (2013).

\section{CONTEXT AND LITERATURE REVIEW}

\section{a. Multiple Intelligences}

According to Fleetham (in Yaumi \& Nurdin, 2013), multiple intelligences or commonly referred to as multiple intelligences are various skills and talents students have to solve various problems in learning. Gardner found eight kinds of plural intelligence, namely: (1) verballinguistic intelligence; (2) logicalmathematical; (3) visual-spatial; rhythmic - music; (5) physical kinesthetic; (6) interpersonal; intrapersonal; and (8) naturalistic. Kinds of multiple intelligences are as follows:

1) Verbal-Linguistic Intelligence

Baum, et al (Yaumi, 2013) say that verbal-linguistic intelligence is the ability to use language, including mother tongue and foreign languages, to express what is in the mind and understand others.

2) Logical-Mathematical Intelligence
Mathematical intelligence is also called logical intelligence and reasoning because it is the basis for solving problems by understanding the principles that underlie the causal system or can manipulate numbers, quantities, and operations. Children who have high logical-mathematical intelligence are very fond of playing with numbers and counting, recognizing patterns, like playing math, like experimenting logically, and so on.

3) Visual-Spatial Intelligence

This intelligence is sensitivity to lines, colors, shapes, spaces, balance, shadows of harmony, patterns, and relationships between these elements. Other components are the ability to imagine, present ideas visually and spatially, and orient correctly

4) Physical-Kinaesthetic Intelligence

Sonawat and Gorgi (in Yaumi \& Nurdin, 2013) physical-kinesthetic intelligence is the ability to use the whole body in expressing ideas, feelings, and using hands to produce or transform something. This intelligence includes special skills such as coordination, balance, dexterity, strength, flexibility, and speed.

5) Rhythmic-Music Intelligence

Music Intelligence is the capacity to think in music to be able to listen to patterns and recognize and perhaps manipulate them. People who have strong musical intelligence not only remember music easily, they cannot get out of musical thinking and are always present everywhere.

6) Intrapersonal Intelligence 
This intelligence can be defined as the ability to understand oneself and act on that understanding. The core components of intrapersonal intelligence are the ability to understand oneself accurately including strengths and limitations, self-intelligence of moods, intentions, motivations, temperaments, and desires, as well as the ability to discipline oneself, understand and respect oneself.

7) Interpersonal Intelligence

Interpersonal intelligence with indicators that are pleasant for others. The attitudes displayed by children in interpersonal intelligence are very soothing and full of peace. This component of interpersonal intelligence is the ability to digest and respond appropriately to various moods, intentions, motivations, feelings, and desires of others in addition to the ability to work together.

8) Naturalistic Intelligence

Naturalistic intelligence is the ability to categorize and create a hierarchy of the state of organisms such as plants, animals, and nature. The core components of naturalistic intelligence are expertise in nature (flora, fauna, cloud formation, mountains), the ability to distinguish members of a species, recognize the existence of other species, and map relationships between several species, both formally and informally.

\section{b. Dance Learning}

Dance Learning is a process that contains a series of student and teacher actions on reciprocal relationships that take place in educational situations in achieving certain goals (Rahmi, et al. 2018). According to Yulianti (2016) said that dance is an art that is directly related to human body movements. The body as the main tool and gestures is a medium for expressing it, becoming a unity that cannot be separated. So that dance learning is a series of learning activities carried out directly by teachers and students related to gestures. According to Pratiwi (2018) said that the purpose of learning dance for students is to express their past experiences creatively, foster and develop their creativity and expressed in the form of creative dance works. So that it can make students oriented to the development of creativity, skills, and appreciation of art that can be done through dance learning at school and can be expressed in the form of art of creative dance work. According to Putri, et al (2016) dance has two basic types namely, individual and social. Individual nature is an expression of the soul that comes from the individual. Social nature of dance movements is inseparable from the influence of circumstances that refer to the interests of the environment.

\section{c. Evaluation Instrument}

Instruments within the scope of evaluation are defined as devices for measuring student learning outcomes that include learning outcomes in the cognitive, affective, and psychomotor domains (Rosidin, 2017). Evaluation is an inseparable part of the learning process. In evaluating a teacher needs a useful 
instrument to measure the level of student ability (Ananda and Fadhilaturrahmi, 2017). Then the understanding of evaluation instruments is an assessment tool used to collect data and information that can be used by teachers. According to Arifin (2013) Evaluation is very useful to improve the quality of the learning system. Evaluation cannot be separated from learning, because the effectiveness of learning can only be known through evaluation. An understanding of this instrument is important because in practice evaluation and assessment, in general teachers always base on the measurement process. In measurement, there must be a measuring instrument (instrument), both in the form of tests and non-tests. There are good measuring devices, some are not good. A good instrument is an instrument that meets certain conditions or rules, can provide accurate data by its function, and only measures a sample of certain behaviors. The characteristics of good evaluation instruments are valid, reliable, relevant, representative, practical, discriminatory, specific, and proportional.

According to Widoyoko (2018) said that the assessment of learning outcomes requires instruments to measure learning outcomes to be assessed. These instruments can be divided into test and non-test instruments. Based on the scoring system the tests can be categorized into two, namely objective tests and subjective tests.

1) Objective tests
Understanding tests, in this case, the form of tests in determining the score of the test results fully depends on the answers/responses of test participants, not influenced by the subjectivity of the examiner. In general there are four types of objective test, namely: true-false, match (matching), multiple-choice, and objective description.

2) Subjective tests

Subjective tests are a form of test that in calculating test result scores in addition to being influenced by the test participants' answers/responses are also influenced by the subjectivity of the examiner/scorer. Subjective tests, generally in the form of description (essay), although not all description tests are subjective. In general, the description test is divided into two forms, namely: a free description test or an open description (extended response) and a limited description test (restricted response).

Assessment of learning outcomes is not only done by tests, but can also be done through non-test measurement instruments or instruments, such as observation guidelines in the form of checklists and rating scales, questionnaires, attitude scales, and assessment rubrics. The instrument for obtaining information on non-test learning outcomes is mainly used to measure learning outcomes regarding skills and attitudes, namely aspects related to what students can make or do rather than what they know or understand. 


\section{METHODS}

This study uses research and development. This development uses design development by Tegeh (2014) with ADDIE models consisting of 1) Analysis, 2) Design, 3) Development, 4) Implementation, and 5) Evaluation (Figure 1). Development procedures that researchers will undertake in developing evaluation instruments with ADDIE models that are tailored to the needs of researchers.

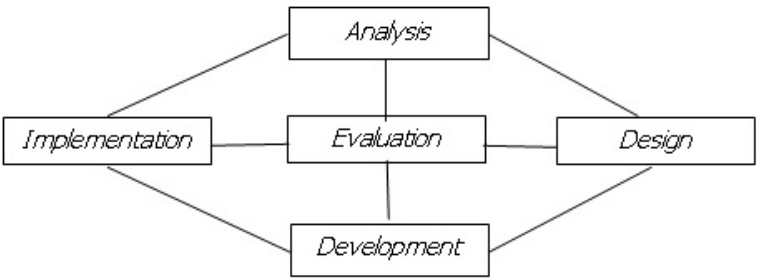

Figure 1. Steps in Developing the ADDIE Model (Sugiyono, 2016)

The development procedure that the researcher will undertake in developing an instrument for evaluating dance learning outcomes based on multiple intelligences in elementary school students modifies the ADDIE development model. In this research, development refers to the ADDIE development research procedures that are tailored to the needs of researchers. This stage starts with the analysis phase (Analysis). The steps of analysis carried out by researchers include four things, namely needs analysis, curriculum analysis, material analysis, and learning analysis. The second stage is planning (Design). Product planning is done by making the desired components and designing the product. The third stage is the development of the product. At this development stage, after going through the planning stage the product is developed under the design of the components that have been made. The fourth stage is the implementation (Implementation), in this study was not carried out until the implementation phase is due to time constraints. So that at this stage can be done by further research. The fifth stage is evaluation (Evaluation), this stage is the final stage to assess and determine the quality of product development in the ADDIE development model.

After the stages of the steps have been identified, the next stage is testing the product. The stages in testing the products need to be known through the design of the trial, the subject of the try, and the type of data. The design phase of the trial in this research product trial is indicated by several steps namely the product is tested on material experts, learning experts, and evaluation experts. After getting an assessment and suggestion, the product is revised. Next test the product to the teacher to obtain data on the feasibility of the instrument for evaluating dance learning outcomes based on multiple intelligences obtained from a questionnaire and testing the students for empirical test data.

The subject of the trial was conducted by material experts, learning experts, evaluation experts, and fourthgrade teachers of SD Muhammadiyah Bantul City. The type of data used in this study is quantitative data and qualitative data. Data collection instruments are 
using questionnaires, interviews, and documentation. In this study we use a closed questionnaire. The data collection questionnaire used in this study is the validation width. Validation with expert judgment involves two experts who examine evaluation instruments, namely:

(a) conformity with learning, conformity of material to curriculum, (c) practice, (d) clarity of assessment guidelines, and (e) language used. The experts also assessed the suitability of items with indicators in the form of a Likert scale with four answer choices. In addition to qualitative assessments from experts and trials, evidence of the validity of the evaluation instruments is also supported by the average number using the formula. The instrument can be said to be feasible if it has a minimum score of 66 in either category.

\section{RESULTS}

Dance learning is a series of learning processes carried out by students and teachers directly related to human body movements. The dance learning process is emphasized to be oriented toward students. So that in the process of learning dance can be used to determine the extent of student development. The development of students viewed from aspects of multiple intelligences. Of the eight types of multiple intelligences available, this study will refer to several aspects of multiple intelligences, namely musical intelligence, visual-spatial, bodily-kinaesthetic, intrapersonal, and interpersonal. The five intelligences are the intelligence that is most suitable for dance learning. The evaluation will be carried out during the dance learning process. On the other hand, each student has different intelligence in learning abilities, so it needs an instrument based on multiple intelligences to find out. The dance learning evaluation instrument based on multiple instances is a solution to find out students' abilities in learning achievement.

The results obtained are based on research that has been done, namely through the stages of ADDIE. This stage starts with the analysis phase. The steps of analysis carried out by researchers include four things, namely needs analysis, curriculum analysis, material analysis, and learning analysis. Based on the needs analysis found problems experienced by fourth-grade teachers of SD Muhammadiyah Bantul City, namely teachers have not used an evaluation instrument to assess student performance. Curriculum analysis is also carried out namely to find out the core competencies and basic competencies used by teachers in grade IV elementary schools. Furthermore, material analysis is carried out to determine the material that is suitable for the development of evaluation instruments, namely the Bungong Jeumpa dance material. The final analysis is a learning analysis conducted to determine the assessment used to develop products in the form of an evaluation instrument for dance learning outcomes based on multiple intelligences. The evaluation instrument will contain three assessments namely 
attitude assessment, knowledge assessment, and skills assessment.

The second stage of the ADDIE model is planning (stage design). Product planning is done by making the components contained in the dance evaluation instrument based on multiple intelligences. Each component is arranged by the needs of the evaluation instrument to be developed. The following can be done in product planning as follows: 1) Design the front cover of the evaluation instrument, 2) Design the identity of the evaluation instrument, and 3) Design the contents of the evaluation instrument. Furthermore, the learning plan that is carried out is making a Learning Implementation Plan (RPP).

The third stage is the development. The product making in this case is an instrument of evaluation of dance learning outcomes based on multiple intelligences. The manufacture of evaluation instruments using Microsoft Word 2010 and CorelDRAW X5 starts from the cover to the contents of the evaluation instruments. The identity of the evaluation instrument consists of the preface and table of contents. The contents of the evaluation instrument consist of several components. These components include attitude assessment (attitude assessment journal, selfassessment, and peer-to-peer assessment), knowledge assessment (test questions, test questions assessment guidelines, and answer keys), skills assessment (filling instructions, score guidelines, criteria guidelines, programs remedial, remedial program, enrichment program, assessment sheet, and assessment rubric), appendices, and bibliography. Then the next step is validation conducted by learning experts and material experts.

The fourth stage is the implementation (Implementation), after being assessed by experts, then the product revision will be carried out before being trialed to the elementary school by the advice and input provided by the experts. After the product is revised and said to be feasible for testing, the next step is to test the product with the test subject. The trial was tested on the fourth-grade teachers of SD Muhammadiyah Bantul City. This trial was conducted to determine the quality of the evaluation instrument of dance learning outcomes based on multiple intelligences in elementary school students.

The fifth stage is evaluation (Evaluation), this stage is the final stage of product development in the ADDIE development model. The evaluation was conducted by researchers to determine the appropriateness of the instrument for evaluating dance learning outcomes based on multiple intelligences in elementary school students. The feasibility comes from the validation data of material experts, learning experts, evaluation experts, and teacher evaluations of the dance learning evaluation instruments based on multiple intelligences on elementary school students that have been developed by 
researchers. Besides, evaluations are carried out starting from product development to evaluation instruments to be said to be suitable for use.

Below are some examples of parts of evaluation instruments that have been developed based on the ADDIE method.

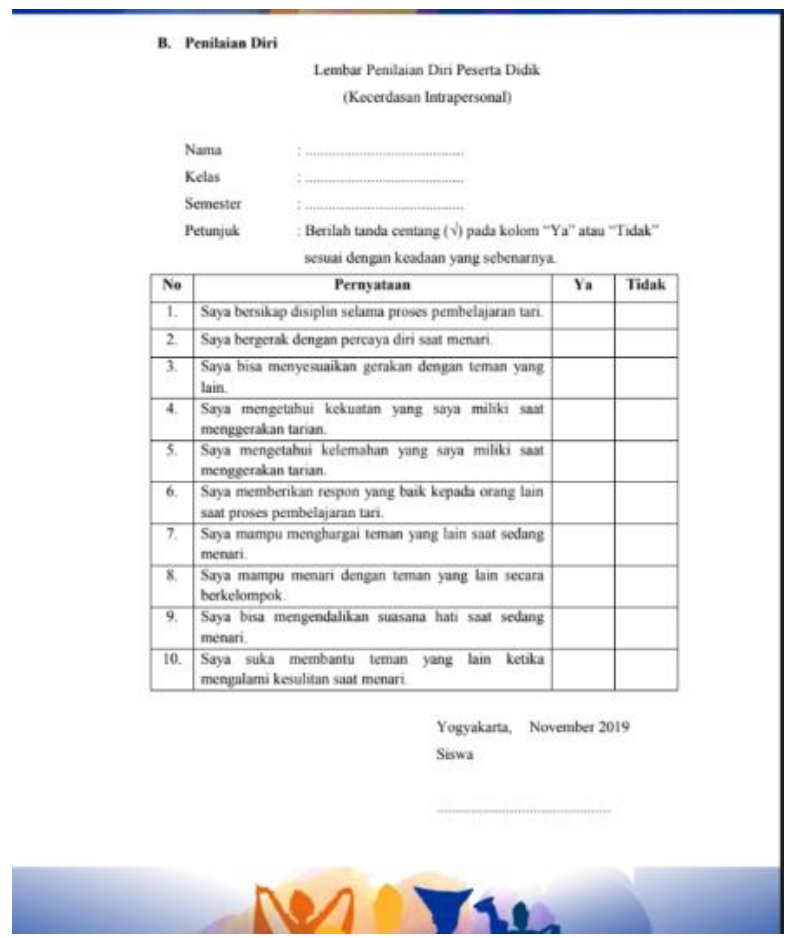

Figure 2. Intrapersonal assessment sheets (Siswantari \& Maretha, 2019)

Figure 2 is an example sheet selfassessment of students (intrapersonal). In this sheet, there are questions related to assessing the ability to judge oneself related to their ability to dance and their self-perception of other people's abilities to dance. Through various questions, the students' intrapersonal intelligence will be known. On the next sheet, there are teacher cross-checks sheets that are assessed based on teacher observations.
Thus the assessment comes from 2 directions, namely individual student assessment and teacher observations during the learning process.

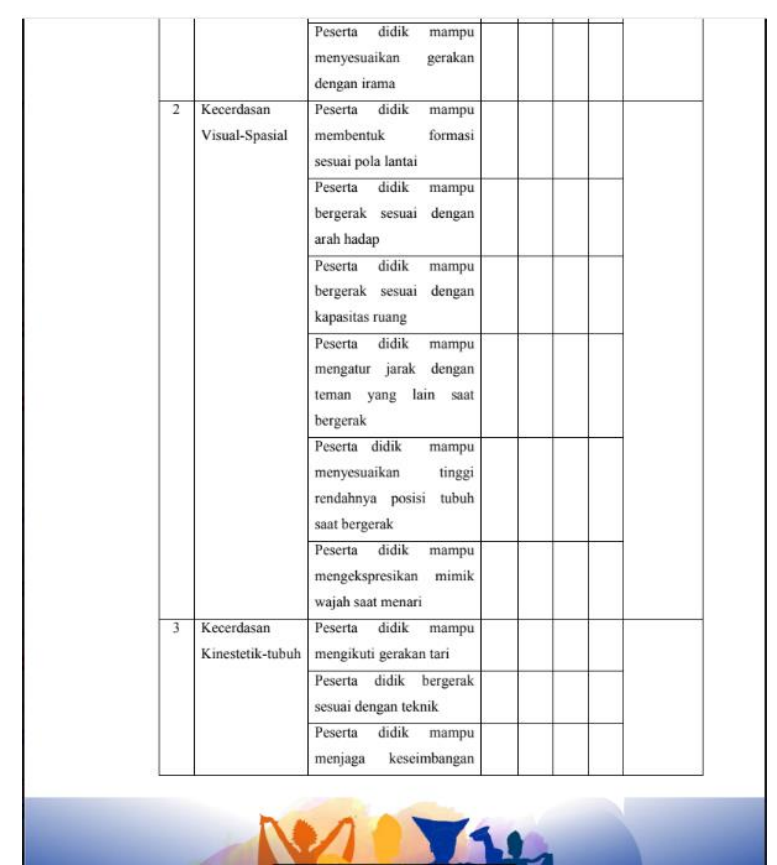

Figure 3. Spatial visual assessment sheets (Siswantari \& Maretha, 2019)

Figure 3 is an example of a skills assessment sheet, namely visual-spatial. In this sheet, it describes how the teacher can see the child's ability to read space and maximize visual-spatial intelligence in dance. Some examples of spatial-visual intelligence in dance are the ability to form floor patterns in groups, the ability to determine the direction facing, the ability to show facial expressions, and so on. Besides, there is also an assessment of musical and kinaesthetic intelligence which is also described in detail for each point.

Data obtained from the results of this study in the form of quantitative data 
and qualitative data. Quantitative data is used to process data obtained from the results of the validation in the form of scores by learning experts, material experts, and teacher assessments. While qualitative data is in the form of input, suggestions, and comments from learning experts, material experts, and teacher responses. The data obtained from the assessment of the experts and the assessment of the teacher as follows.

1. Learning Expert Validation Results

Learning expert validation results, the maximum score from the learning expert questionnaire is 40 . The total score obtained from the learning expert is 37 . So the score obtained is 92.5 and is included in the "Very Good" category in the learning expert assessment results on the quality of the evaluation instruments of dance learning products based on multiple intelligences.

2. Material Expert Validation Result

The Data result of material expert validation, the maximum score from the material expert questionnaire was 36. The total score obtained from the material expert was 34 . So the score obtained was 94 and included in the category of "Very Good" on the results of the material expert assessment of the quality evaluation instrument for dance learning products based on multiple intelligences.

3. Evaluation Expert

The maximum score from the evaluation expert questionnaire is 80 . The total score obtained from the evaluation expert is 62 . So the value obtained is 77.5 and included in the category of "Good" in the evaluation expert evaluation results of product quality evaluation instrument for dance learning outcomes based on multiple intelligences.

4. Teacher Trial Assessment

The data of teacher assessment results, the maximum score from the teacher assessment sheet is 64 . The total score obtained from the learning expert is 61 . So the value obtained is 95 and included in the category of "Very Good" on the results of teacher assessment of product quality an instrument for evaluating dance learning outcomes based on multiple intelligences.

Table 1. Results of Evaluation Instrument

\begin{tabular}{llll}
\hline No. & Experts & Score & Category \\
\hline 1. & $\begin{array}{l}\text { Learning } \\
\text { expert }\end{array}$ & 92.5 & Very good \\
2. & $\begin{array}{l}\text { Material } \\
\text { expert } \\
\text { 3. }\end{array}$ & 94 & Very good \\
expert & 77.5 & Good \\
4. & $\begin{array}{l}\text { Teacher } \\
\text { expert }\end{array}$ & 95 & Very good \\
\hline Total of score & \multicolumn{2}{c}{359} \\
\hline Average of score & \multicolumn{2}{c}{89.75} \\
\hline Category & \multicolumn{2}{c}{ Very good } \\
\hline
\end{tabular}

Based on these results, the development of instruments for evaluating dance learning outcomes based on multiple intelligences is feasible to be used in dance learning in elementary schools as a guide for teachers in evaluating dance learning outcomes based on multiple intelligences. The evaluation instrument contains assessments that refer to the theory of 
multiple intelligences that can be used by the teacher.

\section{DISCUSSION}

The instrument for evaluating dance learning outcomes based on multiple intelligences in elementary school students has been developed. This instrument is different because it refers to multiple intelligences that have been adapted to core competencies and elementary school assessment manuals. The instrument for evaluating dance learning outcomes based on multiple intelligences consists of several components. These components include attitude assessment (attitude assessment journal, self-assessment, and peer-topeer assessment), knowledge assessment (test questions, test questions assessment guidelines, and answer keys), skills assessment (filling instructions, score guidelines, criteria guidelines, programs remedial, remedial program, enrichment program, assessment sheet, and assessment rubric), appendices, and bibliography.

The evaluation instrument was developed as a guide for the teacher in evaluating dance learning outcomes based on multiple intelligences. The evaluation instrument contains assessments that refer to the theory of multiple intelligences that can be used by the teacher. These assessments are:

\section{Attitude assessment}

Attitude assessment is an assessment consisting of intrapersonal intelligence and interpersonal intelligence. In attitude assessment, there are indicators developed according to each intelligence. The indicators contained in attitude assessment are discipline, selfconfidence, knowing the strengths and weaknesses possessed, giving good response, mutual respect, working together, communicating well, helping each other, leading, motivating, empathizing, and controlling mood.

2. Knowledge assessment

Knowledge assessment is an assessment consisting of knowledge test questions. In the assessment of the knowledge, there are general knowledge questions that are tailored to the learning material, namely about the Bungong Jeumpa dance. Questions in the form of multiple-choice and essay. Besides, there are also answer keys and guidelines for the assessment of test questions.

3. The assessment of skills

The assessment of skills consists of rhythmic-musical intelligence, visualspatial intelligence, and kinaesthetic-body intelligence. Each intelligence is derived into several indicators, namely: (a) rhythmic-musical intelligence consisting of musical suitability, the length of the beat of the music, the speed of the music, the time of starting the music, the time of the cessation of the music, and the rhythm floor, face direction, space capacity, distance, the position of height and facial expression, (c) kinaestheticbody intelligence consists of technique, balance, speed, strength, and coordination. The assessments of skills have been equipped with filling instructions, score guidelines, criteria guidelines, remedial programs, and 
enrichment programs. So that teachers can easily use the learning evaluation instruments based on multiple intelligences that have been developed.

Previous research has examined the development of a dance learning design in the form of a portfolio instrument with the approach of Integrated Learning (Sustiawati et al, 2018). This evaluation instrument certainly complements the learning tool as an evaluative function of dance learning in elementary schools. Multiple intelligence-based assessments are not only in the form of instruments but also in portfolio assessment (Mediartika \& Aznam, 2018) and the form of student worksheets (Ernawati et al, 2017). Evaluation instruments are important to continue to be developed to produce output under the changing times. Social change and technological development require us to always innovate in learning, one of which is in the development of learning evaluation instruments. Dance as one branch of art should be able to be evaluated objectively and measured so that it is not considered abstract or subjective in its assessment. This dance evaluation instrument based on multiple intelligences is not only suitable for use in elementary schools but in dance learning at various levels with material adjustments in it. We need to understand that dance assessment is not only limited to kinaesthetic and musical aspects as depictions of wiraga, wirama, and wirama. However, it also assesses all aspects of the learning process so that other intelligence that is formed in students will be seen.

\section{CONCLUSION}

Development of instruments for evaluating dance learning outcomes based on multiple intelligences in elementary school students using the ADDIE development model. Evaluation instruments have been developed through several stages of development, namely analysis, design, development, implementation, and evaluation. The instrument for evaluating dance learning outcomes based on multiple intelligences consists of several components, namely: attitude assessment (attitude assessment journal, self-assessment, and peer-topeer assessment), knowledge assessment (test questions, test questions assessment guidelines, and answer keys), skills assessment (instructions filling, score guidelines, criteria guidelines, remedial program, remedial program, enrichment program, assessment sheet, and assessment rubric), appendix, and bibliography. This instrument is very suitable to be used by dance instructors to assess the intelligence that arises in students during the dance learning process. This instrument can still be developed in material aspects and assessments of other intelligence such as language, naturalistic, mathematical, and spiritual logic as intelligence added recently by experts who have not yet been summarized in this evaluation instrument. 


\section{REFERENCES}

Ananda, R., \& Fadhilaturrahmi, F. (2017). Evaluasi Pembelajaran IPS Berbasis Taksonomi Bloom Dua Dimensi di Sekolah Dasar. Jurnal Basicedu, 1(2), 12-21. DOI: 10.31004/basicedu.v1i2.2

Arifin, H. (2017). Konsep Multiple intelligences System Pada Sekolah Menengah Pertama Al Washliysh 8 Medan Dalam Perspektif Islam. Jurnal Edutech, 3(1), 52-73. https://doi.org/10.30596/edutech.v3i 1.986

Arifin, Z. (2013). Evaluasi Pembelajaran "Prinsip, Teknik, Prosedur". Bandung: PT Remaja Rosdakarya.

Dirman, D., \& Juarsih, C. (2014). Penilaian dan Evaluasi. Jakarta: PT Rineka Cipta.

Ernawati, A., Ibrahim, M. M., \& Fief, A. (2017). Pengembangan Lembar Kerja Siswa Berbasis Multiple Intelligences Pada Pokok Bahasan Substansi Genetika Kelas XII IPA SMA Negeri 16 Makassar. Jurnal Biotek, 5(2), 118. http://journal.uinalauddin.ac.id/index.php/biotek/articl e/view/4276/3999

Mediartika, N \& Aznam, N. (2018). Pengembangan Instumen Penilaian Portofolio Berbasis Multiple Intteligence Untuk Mengukur Kemampuan Berpikir Kritis dan Sikap Ilmiah. Jurnal Inovasi Pendidikan IPA 4 (1), 52-63. https://journal.uny.ac.id/index.php/ji pi/article/view/9973

Pratiwi, E. Y. R., \& Asmarani, R. (2018). Kualitas Media Card Dance Untuk
Pembelajaran Seni Tari di Lembaga Pendidikan. Jurnal Bidang Pendidikan Dasar, 2(2), 1-10. https://doi.org/10.21067/jbpd.v2i2.2 $\underline{534}$

Putri, R., Supadmi, T., \& Ramdiana, R. (2016). Bentuk Penyajian Tari PHO di Gampung Simpang Peut Nagan Raya. Jurnal IImiah Mahasiswa Program Studi Pendidikan Seni Drama, Tari dan Musik, 1(2), 117-125. http://www.jim.unsyiah.ac.id/sendrat asik/article/viewFile/5257/2193

Rahmi, S. A., Yuliasma, Y., \& Susmiarti, S. (2018). Hubungan Minat Terhadap Hasil Belajar Siswa Dalam Pembelajaran Seni Tari di SMP N 4 Padang. Jurnal Sendratasik, 6, (2) 16-22.

http://ejournal.unp.ac.id/index.php/s endratasik/article/view/102732

Rofiah, N. H. (2016). Menerapkan Multiple Intelligences Dalam Pembelajaran di Sekolah Dasar. Jurnal Dinamika Pendidikan Dasar, 8, (1), 68-79. DOI: 10.30595/dinamika.v8i1.937

Rosidin, U. (2017). Evaluasi dan Asesmen Pembelajaran. Yogyakarta: Media Akademi.

Rosnawati, R. (2017). Pengembangan Instrumen Penilaian Kemampuan Menari Pada Peserta Didik Sma Negeri 3 Watansoppeng Kabupaten Soppeng. Jurnal Penelitian dan Evaluasi Pendidikan, 1(1), 59-65. https://ojs.unm.ac.id/UEA/article/vie $\underline{w / 3786}$ 
Sugiyono, S. (2016). Metode Penelitian dan Pengembangan Research and Development. Bandung: Alfabeta.

Sundari, S., \& Setyo, R. (2016). Pengembangan Kepribadian dalam Pembelajaran Seni Tari di Sekolah. Jurnal Imajinasi, 10(1), 61-66. https://doi.org/10.15294/imajinasi.v1 $\underline{0 i 1.8817}$

Sustiawati, N. L., Suryatini, N. K., \& Anak Artati, A. A. M. (2018). Pengembangan Desain Pembelajaran Seni Tari di Sekolah Dasar Berbasis Localgenius Knowledge Berpendekatan Integrated Learning. Jurnal Seni Budaya, 33(1), 128-143. https://doi.org/10.31091/mudra.v33i 1.322

Suyono, S., \& Hariyanto, H. (2012). Belajar dan Pembelajaran; Teori dan Konsep Dasar. Bandung: PT Remaja Rosdakarya.
Tegeh, I M., Jampel, I. N., \& Pudjawan, K. (2014). Model Penelitian Pengembangan. Yogyakarta: GRAHA ILMU.

Undang-Undang RI No. 20 Tahun 2003 tentang Sistem Pendidikan Nasional. Jakarta: Depdiknas.

Widoyoko, E. P. (2018). Penilaian Hasil Pembelajaran di Sekolah. Yogyakarta: Pustaka Pelajar.

Yaumi, M., \& Ibrahim, N. (2013). Pembelajaran Berbasis Kecerdasan Jamak (Multiple Intelligences) Mengidentifikasi dan Mengembangkan Multitalenta Anak. Jakarta: Kencana.

Yulianti, R. (2016). Pembelajaran Tari Kreatif Untuk Meningkatkan Pemahaman Cinta Lingkungan Pada Anak Usia Dini. Jurnal Pendidikan dan Kajian Seni, 1(1), 29-42. DOI: http://dx.doi.org/10.30870/jpks.v1i1. 851 